\title{
Intra-Site Structure of the Early Ahmarian Site of Al-Ansab 1, AH 1 (Jordan)
}

\author{
Jonathan Schoenenberg ${ }^{1}$ (i) $\cdot$ Florian Sauer ${ }^{1}$ (I)
}

Accepted: 26 August 2021/Published online: 04 January 2022

(C) The Author(s) 2022

\begin{abstract}
The Early Ahmarian represents an Early Upper Palaeolithic cultural unit, which spans throughout the Levant to the Sinai Peninsula. At least 40 sites belong to this unit. Both open-air and cave sites provide different amounts of archaeological material at various spatial resolutions. The team of the Collaborative Research Centre 806 "Our Way to Europe" excavated the site of Al-Ansab 1, Wadi Sabra, since 2009. The site provides one of the largest lithic assemblages of the Early Ahmarian. Analysis of intra-site distributions and patterns has been conducted for a small number of sites, providing scarce information on the spatial makeup of Early Ahmarian occupation layers. The internal structure testifies to repeated settlement without task specialisation. While this has been described for the sites on the Sinai Peninsula, the situation has been unclear for locations placed in the escarpments of the Transjordanian Highlands. At Al-Ansab 1 , we can observe the repeated, relatively ephemeral occupation of a specific location in the Wadi Sabra for the execution of various tasks such as processing of faunal elements and raw material exploitation. Our results correlate to a pattern of mobility observable at other Early Ahmarian sites such as Abu Noshra II. These sites are usually attributed to relatively small and highly mobile bands of hunter-gatherers. Analysing these patterns of intra-site and regional spatial behaviour in the context of environmental patterning highlights potential external drivers to the expression of human occupation at sites such as Al-Ansab 1, archaeological horizon 1.
\end{abstract}

Keywords Early Ahmarian · Intra-site analysis · GIS · Mobility pattern · Levant

Jonathan Schoenenberg

j.schoenenberg@uni-koeln.de

Florian Sauer

Florian.sauer@uni-koeln.de

1 Department of Prehistoric Archaeology, University of Cologne, Cologne, Germany 


\section{Introduction}

About 45,000 years ago, anatomically modern humans began to permanently establish themselves in the Levant (Alex et al. 2017; Hershkovitz et al. 2015; Hublin 2015; Richter et al. 2020). Humans expanded into the Mediterranean biome along the shores of the Mediterranean Sea in the context of the Early Ahmarian cultural unit. From there, they populated marginal areas in a second phase of expansion (Richter et al. 2020). The arid environments of the Irano-Turanian steppe and the Saharo-Arabian biome came into focus. Numerous sites in the eastern escarpments of the Jordan Rift Valley, the Negev Desert and the Sinai Peninsula attest to this phase of further expansion (Richter et al. 2020; Miebach et al. 2019).

About 40 sites are associated with the Early Ahmarian dating to c. 46,000/42,00031,000/29,000 cal. BP (Sauer and Schoenenberg 2021; Belfer-Cohen and GoringMorris2018; Richter et al. 2020). Thirteen of them were subject to extensive excavation paired with a spatial analysis of archaeological finds (Table 1). Intra-site spatial analysis as well as refitting of artefacts permit insights into the internal structuring of these locations. Patterns of artefacts reflect both on-siteactivities and the position of a location in a mobility system covering a larger area. Marks and Friedel (1977) assume a pattern of high mobility for sites in the Negev Desert. This is also corroborated by locations such as Abu Noshra I and II in the Wadi Feiran (Becker 2003).

Beside Al-Ansab 1, only two locations show more than one distinct occupation layer among the spatially analysed sites (Gilead and Bar-Yosef 1993; Bar-Yosef and Belfer 1977b). These sites lie in the Negev Desert and the Sinai Peninsula. The intense erosion in the wadis of the eastern escarpments of the Rift Valley makes site preservation a major issue. To date, sites are rare in this area. The environmental conditions in the escarpment zone were different when compared to the areas of the Negev and the Sinai Peninsula at the time of the Early Ahmarian (Richter et al. 2020; Miebach et al. 2019; Sauer and Schoenenberg 2021). The Negev and the Sinai were landscapes dominated by the Saharo-Arabian biome (desertic and semi-desertic), while the southern escarpment zone was covered by the steppe environment of the Irano-Turanian biome. In combination with the geomorphological makeup, these landscapes form different backdrops to human life during the Early Ahmarian. Consequently, it remains an important question to which point these variations translated to the internal setup of archaeological locations in the escarpment zone.

In the past 11 years, the team of the Collaborative Research Centre 806 "Our Way to Europe" investigated the upper archaeological horizon 1 (AH 1) of Al-Ansab 1 (Fig. 1a). This site provided a large lithic assemblage (Table 1). Joint research by the Universities of Aachen, Cologne and Amman generated detailed spatial information. Simultaneously, the geological history of the lower Wadi Sabra was investigated, contextualising the site of Al-Ansab 1 within the local sedimentological history (Bertrams 2013; Bertrams et al. 2014, 2012).

The extent of the excavation area allowed the investigation of intra-site artefact patterning. Seven excavation campaigns between 2009 and 2020 generated a large dataset of three-dimensional information on find distribution. In this paper, we aim to discuss the distribution of different find categories which could be determined in the excavated area at the site. We seek to understand the internal structuring of Early Ahmarian sites in the Transjordanian escarpment zone in comparison to locations in the 


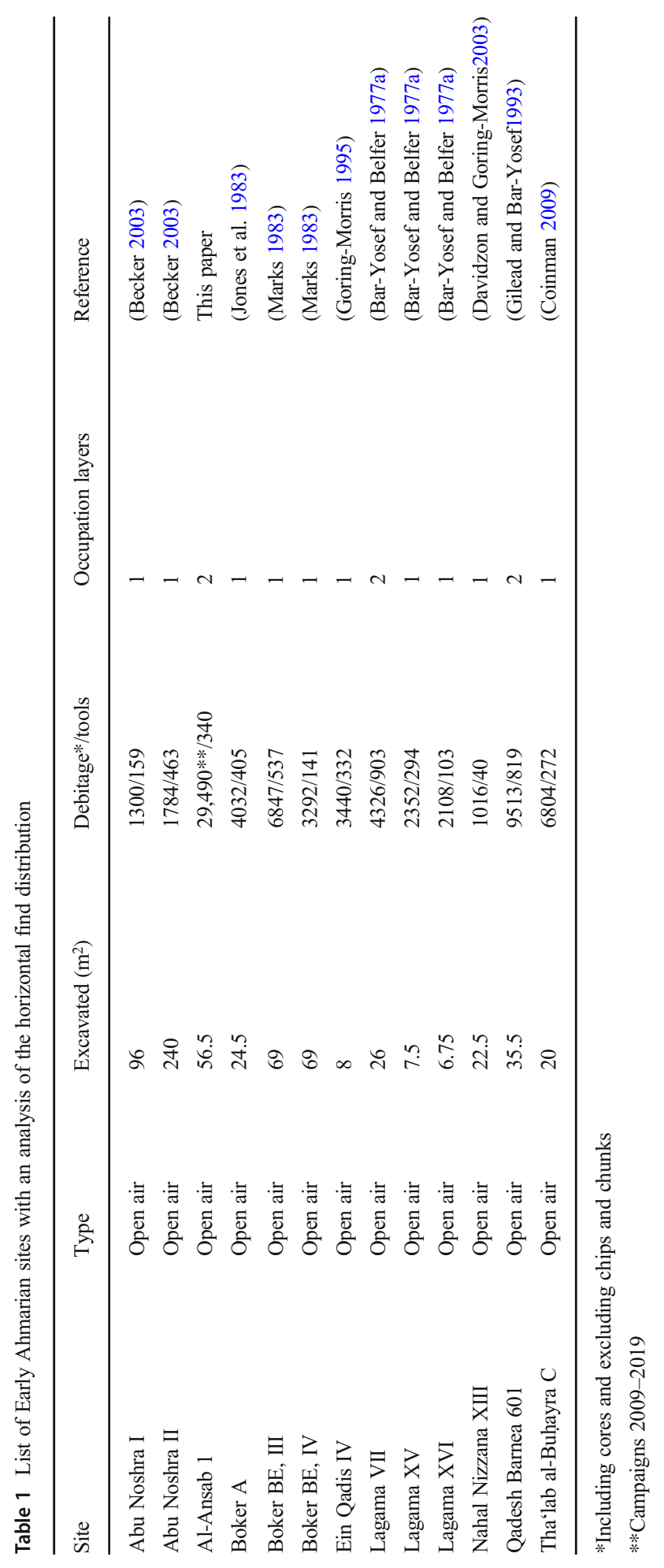




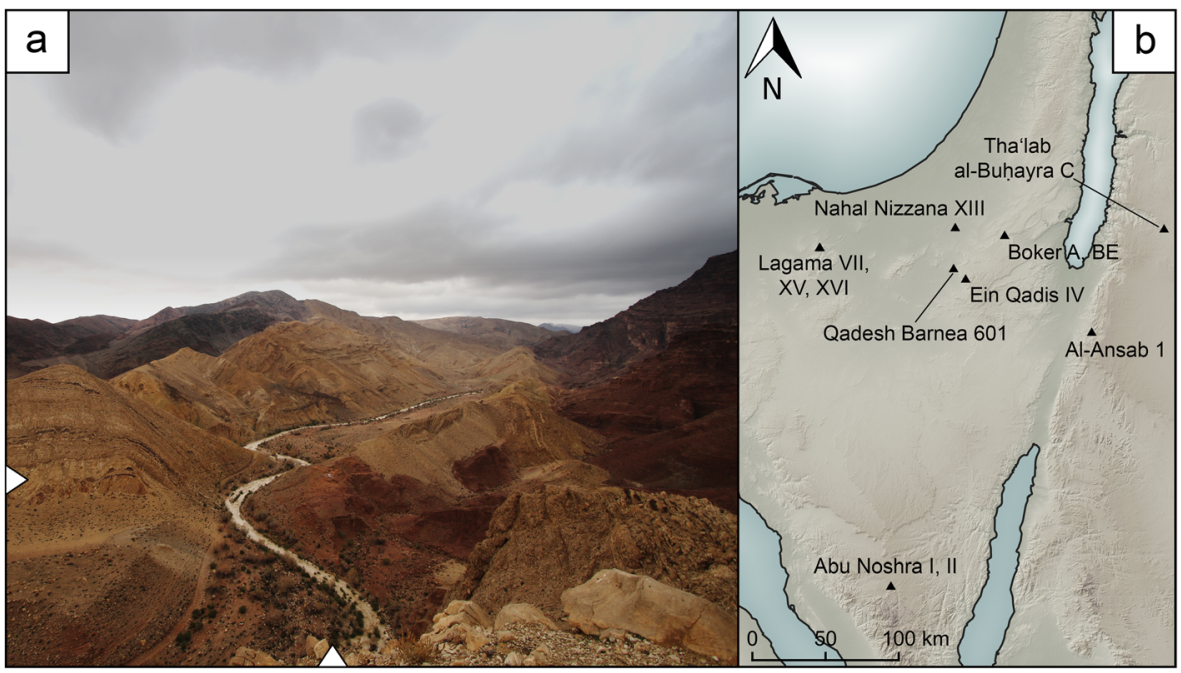

Fig. 1 a Photo of the site of Al-Ansab 1 in the Wadi Sabra during flash flood event (13 February 2018, view to the north); the arrows indicate the location of the site. $b$ The location of Al-Ansab 1 and other sites of the Early Ahmarian with spatial intra-site analysis mentioned in this text

West of the cultural unit. Since environment and landscape provide substantially different conditions, such comparisons can highlight adaptions of hunter-gatherers to local conditions.

\section{Material and Methods}

\section{The Site of Al-Ansab 1, AH 1}

The site of Al-Ansab 1 (Fig. 1a, b) in the Wadi Sabra was first discovered during the TAVO (Tübinger Atlas des Vorderen Orients) survey in 1983 (Schyle 2015b). In 2008, the Collaborative Research Centre 806 "Our Way to Europe" took up research into Palaeolithic sites in the region. Survey of the entire Wadi Sabra provided a full view on sites from the Middle Palaeolithic to the Nabatean era. The first excavations began at Al-Ansab 1, AH 1 (Schyle 2015c; Richter et al. 2015), in 2009, followed by six field campaigns of which the last took place in the Spring of 2020 (Fig. 2). In addition to archaeological excavations, geological investigations focussed on the landscape evolution in the Wadi Sabra (Bertrams 2013; Bertrams et al. 2014, 2012). It highlighted both the geological processes that led to the current wadi morphology, as well as the ecological and sedimentological regime at the time of occupation.

Today, Al-Ansab 1 lies on a sediment remnant c. $20 \mathrm{~m}$ above the current valley floor. A nearby limestone ridge protects the archaeological layers of Al-Ansab 1, shielding the Pleistocene sediments of the promontory from erosion by the discharging wadi. Remote sensing investigations showed that goethite-richsediments-also found at Al-Ansab1 - indicate remnants of the Pleistocene landscape. Several of those remnants occur along the course of the wadi (Löhrer et al. 2013). During the time of Early Upper Palaeolithic occupation, the wadi was filled to the level of the site. This provided 


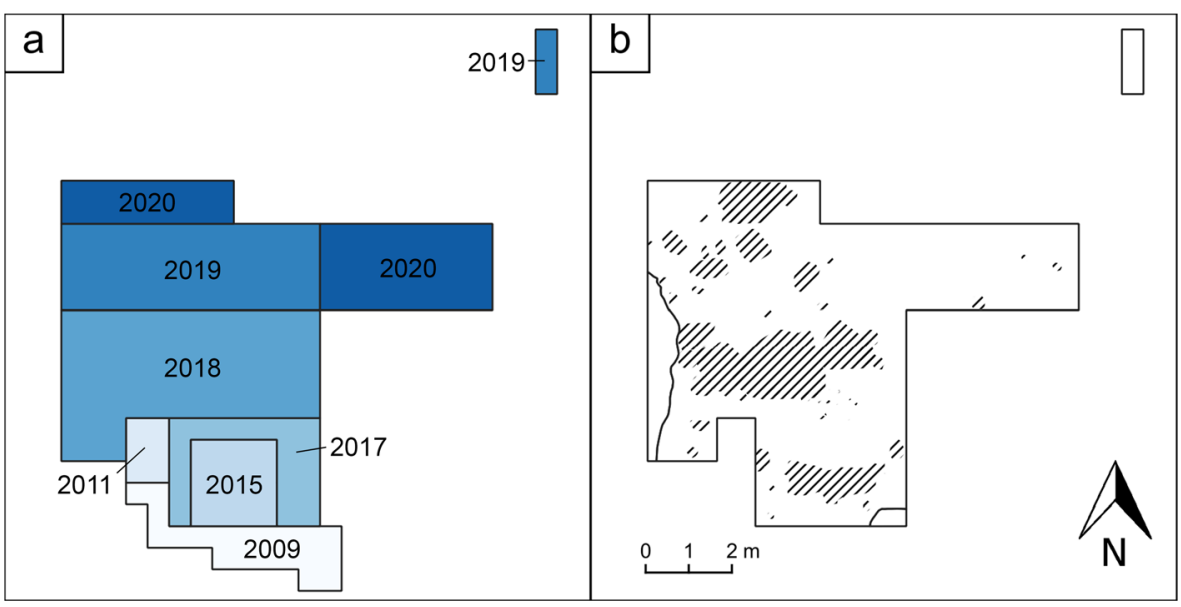

Fig. 2 The excavated areas at Al-Ansab 1, AH 1. a Excavation by campaigns. b Features (hashed areas) that were observed in the excavated area

a more open space for human activity (see Richter et al. 2020, Fig. 3C). During MIS 3, an almost continuous aggradation of sediments took place (Bertrams 2013; Schyle 2015b; Bertrams 2015). At the base of the sediment sequence, coarse-grained sediments indicate high energy deposition, possibly dating to the Middle Pleistocene (Bertrams 2013). By the end of MIS 4 or the beginning of MIS 3, the sedimentological regime changed towards finer deposits interrupted by high energy discharge events and colluvial processes. During the mid-MIS 3, a generally calmer aggradation took place in the lower Wadi Sabra. Intercalated calcretes attest to consolidation of these sands and to initial soil formations. The occupation of Al-Ansab 1, AH 1, is embedded in a sediment layer comprised of sands of sheet flow and fluvio-aeolian origin (Richter et al. 2020). This indicates an environment which is slightly more humid than today. The continuous deposition of fine-grained sands generally indicates a less seasonal rainfall pattern in the region, resulting in the absence of destructive flash flood events (Bertrams 2013). Low-energy aggradation continues after the occupation at Al-Ansab 1, AH 1, for some time. Younger sediments, post-dating the timeframe of about 35 to $30 \mathrm{ka} \mathrm{BP}$, are not preserved in the Al-Ansab sediment column due to erosion.

OSL data from the promontory where Al-Ansab 1 is located suggest that the entire MIS 3 stratigraphy developed within a relatively short time span of several thousand years (Bertrams et al. 2012, p. 65; Klasen et al. 2013). In addition, four ${ }^{14} \mathrm{C}$ samples on charcoals date $\mathrm{AH} 1$ to $37,890 \pm 630$ a and $36,963 \pm 610$ cal BP, thus attesting human activities during the Greenland Interstadial 8 (Richter et al. 2020, p. 14).

The site provides two archaeological layers separated by a sterile sediment package of c. $160 \mathrm{~cm}$ thickness (Richter et al. 2015). In this paper, we only discuss the upper layer. AH 1 of Al-Ansab 1 was documented over an area of $56.5 \mathrm{~m}^{2}$. To date, the lower layer (AH 2) remains subject to further investigation. The first excavation campaigns focused on determining the in situ placement of the upper layer. Since 2015, largerscale excavations included the individual three-dimensional find locations using a total station. The last excavation campaign ended in spring 2020. 


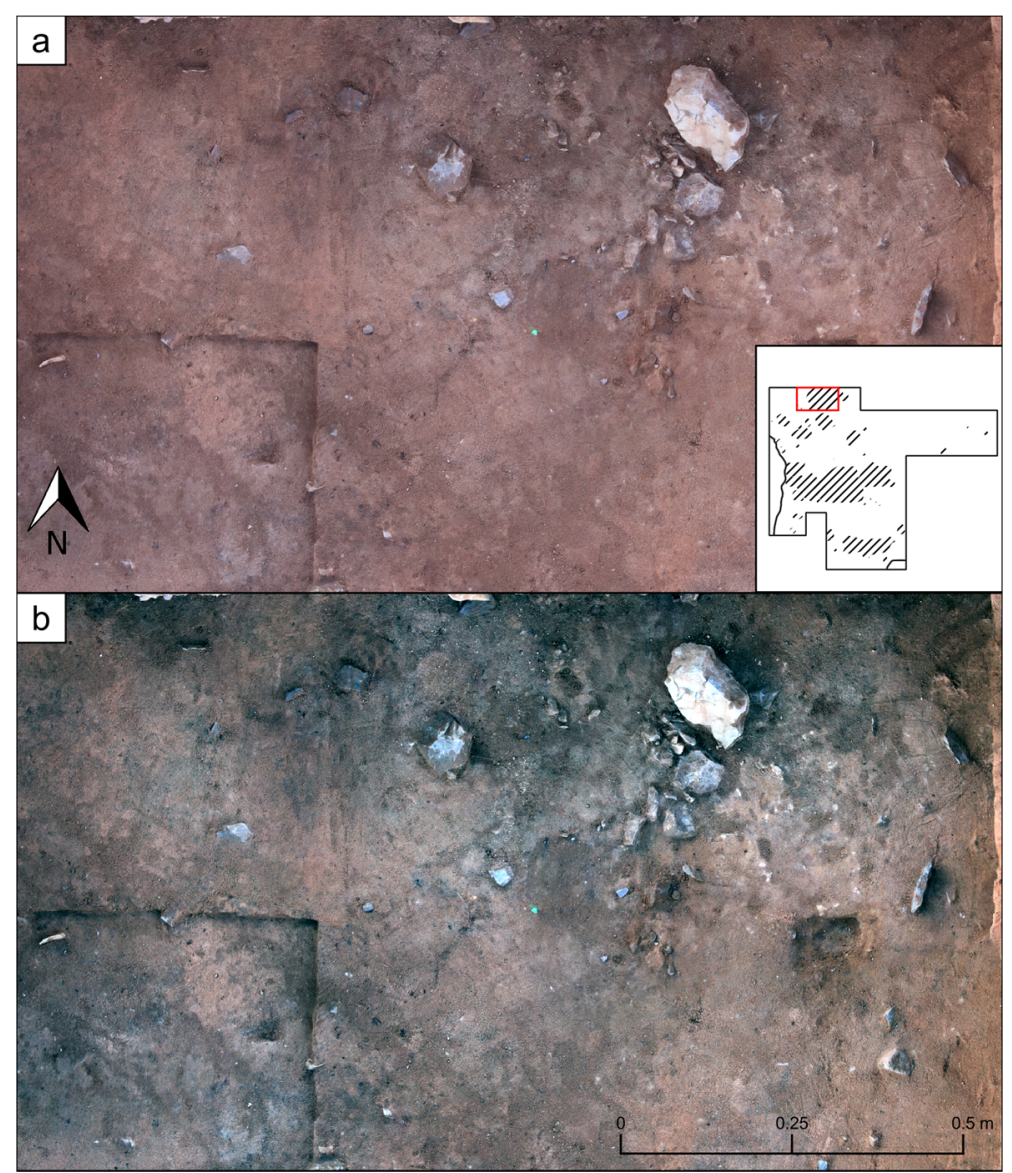

Fig. 3 Orthophoto of feature 59 in the trench of 2020 showing the dark discoloration. a Unprocessed orthophoto. b Orthophoto with intensified contrast to highlight the dark discolorations

A large number of lithic artefacts, bone fragments, traces of ochre and charcoal fragments were discovered during the excavations. Hussain (2015), Schyle (2015a) and Parow-Souchon (2020) partially analysed the lithic assemblage. Currently, Jacopo Gennai further investigates the lithic assemblage at the Collaborative Research Centre at the University of Cologne. To date, more than 57,000 lithic artefacts make up the assemblage of AH 1. The three-dimensional position of 20,360 artefacts (2015-2020) was documented by using Leica TS06ultra-2. Attribute analysis data is currently available for the finds from the excavation campaigns 2015-2019 (Table 2). Orientation and inclination of finds were investigated using the data from 2015 to 2020, while the smaller dataset from 2015 to 2019 was used for the analysis of intra-site patterns.

Numerous dark discolorations were observed during excavation in the sediments of AH 1 (Fig. 3b). We considered these locations to be remnants of fireplaces. Currently, the sediments are under examination. On site, the patches appeared to carry a greater number of artefacts than the surrounding areas (Fig. 3). Delineating the features proved difficult in some cases. The borders were often diffuse and-depending on the lighting 
Table 2 Inventory of excavated finds (2015-2019)

\begin{tabular}{lll}
\hline Artefact category & Amount & Frequency (\%) \\
\hline Materials & & \\
Flint & 52,565 & 94 \\
Rocks (non-flint) & 578 & 1 \\
Charcoal pieces & 235 & $<1$ \\
Ochre pieces & 663 & 1 \\
Faunal remains & 1742 & 3 \\
Other materials & 57 & $<1$ \\
$\boldsymbol{\Sigma}$ & 55,840 & 100 \\
Cores and debitage & & \\
Cores & 277 & 1 \\
Flakes & 12,789 & 24 \\
Blades & 5112 & 10 \\
Bladelets (width $<1.2 \mathrm{~cm})$ & 11,312 & 22 \\
Chunks & 22,354 & 43 \\
Other & 721 & 1 \\
Chips (<1 cm) & $\sim 1.9 \mathrm{~kg}$ & - \\
$\boldsymbol{\Sigma}$ & 52,565 & 100 \\
Tool types & & \\
El-Wad points & 106 & 31 \\
Burins & 47 & 14 \\
End-scrapers & 54 & 16 \\
Notched/denticulates & 20 & 6 \\
Edge-retouched pieces & 79 & 23 \\
Burin spalls & 34 & 100 \\
$\boldsymbol{\Sigma}$ & 340 & \\
\hline & & \\
\hline & & \\
\hline
\end{tabular}

conditions and sediment humidity - hard to discern. In general, features were larger and more diffuse on top and more constrained and defined in lower levels.

Rates of single-plotted finds vary during the different excavation campaigns. In 2015 , c. $14-31 \%$ of all finds were documented in three-dimensional position. In later campaigns, more than $50 \%$ of all finds were documented by total station (Online Resource 1). Also, the southern part of the excavation area contained several large animal burrows. Their number decreased towards the North. These conditions, together with improvements in excavation technique during the years, explain the deviation of conditions in the 2015 section.

The site of Al-Ansab 1 lies at a distance of c. $30 \mathrm{~m}$ to a high-quality raw material outcrop which was used for the production of the artefacts at the site (Parow-Souchon 2020). The substantial number of lithic artefacts represents all stages of the core reduction process. It also indicates a relatively long sequence of occupation and reoccupation of the excavated area (Richter et al. 2020; Parow-Souchon 2020). 
The local context of the Wadi Sabra was relatively humid. A nearby spring provided water all year round. Furthermore, the water retention capabilities of the MIS 3 sediment fill of the wadi made the location a favourable habitat for plants and animals (Parow-Souchon 2020). The faunal assemblage of Al-Ansab 1, AH 1, was characterised by the presence of Gazella sp. (Parow-Souchon 2020; Sauer and Schoenenberg 2021). This corresponds to several other sites of the Early Ahmarian in the region, where Gazella sp. dominates the faunal assemblages (Sauer and Schoenenberg 2021).

\section{Excavation Method}

The excavation at Al-Ansab 1, AH 1, was organised in a $0.25-\mathrm{m}^{2}$ grid since the campaign of 2015. We removed the covering sediments to about $10 \mathrm{~cm}$ above the find layer before continuing in 5-cm spits. When observed, we followed natural layers during excavation. Finds larger than $1 \mathrm{~cm}$ were documented by total station single measurements, whereas finds larger than $2 \mathrm{~cm}$ were measured with at least 2 points. We sieved all sediments and attributed the finds to the individual quarter square metres. The measurements were carried out in a local, north-facing coordinate system (Fig. 2a).

\section{Analysis}

We analysed the data using the Quantum GIS (QGIS) software package 3.10 (QGIS, D. T. 2020) and $\mathrm{R}$ version 3.6.2 (R Core Team 2019) to conduct the statistical analysis. The analysed data includes flint objects, faunal remains, charcoal and larger non-flint stones (Table 2, Fig. 7). Single-plotted finds were documented with up to eight coordinates. We converted measurements to single-point data for further processing concerning find densities. A three-dimensional centroid represented each object by combining the mean coordinate of each find with its mean elevation. Flint artefacts measured with 2 points provided a sample to calculate the orientation and inclination from the three-dimensional data. This information was used to map spatial variation within the layer throughout the excavated area (compare to McPherron 2005, 2018). The excavation campaigns 2015-2019 could provide data for this analysis. Areas of particularly high find density are identified using a kernel density estimation. We employed the Heatmap plugin for QGIS, applying a bandwidth of $0.5 \mathrm{~m}$. The find density showed great variation within the layer, necessitating a methodology highlighting clusters of relatively low density. Thus, high-density hotspots appear less pronounced while emphasising ephemeral, but relatively discrete activities. The applied method works analogous to the topographic position index or deviation from mean elevation (DEV)(Wilson and Gallant 2000, p. 74f; De Reu et al. 2013). "DEV measures the topographic position as a fraction of local relief normalised to local surface roughness" (De Reu et al. 2013, p. 42). Analogous to DEV, we apply the local density index (LDI) as a function of deviation of mean local kernel density:

$$
\mathrm{LDI}=\left(d_{0}-\bar{d}\right) / \mathrm{SD}
$$

where $d_{0}$ is the density value at the focal raster cell as generated by the Heatmap plugin for the point layer of the finds, $\bar{d}$ is the mean density in the search radius and SD is the 
$1 \sigma$ standard deviation in the search radius. The LDI provides a value for local intensity of find density. The search radius should be selected based on research question and find density. In our case, we selected a radius of $1 \mathrm{~m}$. At Al-Ansab 1, AH 1, find densities can represent areas of increased activity, which will not be visible by mapping global densities. The LDI describes the patterning of find distributions more clearly. A value smaller than 0 reflects a density, which is lower than densities in the search radius. A value around 0 reflects equal densities, and a value greater than 0 shows a greater density compared to those in the search radius. We calculated the LDI for the major find material such as flint artefacts, rocks (non-flint lithic objects), charcoals and faunal remains (bone, tooth, eggshell, shell). Flint artefacts were further subdivided by other technological and typological categories. As standard, we used an LDI $\geq 1$ to delineate areas of particularly high find concentration.

We generated a focal diversity value using the Shannon diversity index $(H)$ (Shannon 1949) to calculate the spatial variability of toolset composition. By calculating the diversity index within a given radius of an equally spaced grid of points, the spatial variability of diversity could be represented. For instances, where a tool-type category was not present, the value 0 was given for this specific category. We selected $e$ as the log base for the Shannon entropy since the data used in this article represents count data. All values were normalized to $H_{\max }$. For GIS processing, we used a radius of $35.35 \mathrm{~cm}$ and a focal point spacing of $25 \mathrm{~cm}$. A search radius of 35.35 covers the entire quarter square metre.

\section{Results}

\section{Find Orientation and Inclination}

To evaluate possible post-depositional processes, we considered two main factors in this analysis: artefact orientation and artefact inclination along the longitudinal axis.

We used a sample of 6651 lithic artefacts documented by two measurement points to map artefact orientation (Table 3). Horizontal artefacts were excluded, as they do not plunge and hereby cannot be assigned properly to an unambiguous cardinal direction. To test against uniformity, a Kuiper's test was conducted in R (Arsham 1988; Agostinelli and Lund 2017), as it is suited to test multimodal distributions ( $\mathrm{Li}$ et al. 2020, p. 3). A $k$ value of 3.21 suggests to reject uniformity for the complete dataset. The finds are slightly unbalanced to the north of the excavation area (Fig. 4). However, sample size strongly effects the test statistic (McPherron 2018), which complicates the comparison with other sites. An iteration of 10,000 samples of 500 artefacts yielded uniform distributions in $78 \%$ of the cases. The finds show no dominant orientation but rather a random distribution.

We used a sample of 7375 lithic objects documented by two total station measurements and a minimum planar distance between both points of $1 \mathrm{~cm}$ to analyse artefact inclination (Table 4). Half of the sample shows an inclination under $10^{\circ}$. Only about $17 \%$ is inclined more than $30^{\circ}$ (Fig. 5). Based on these results as well as the regular artefact orientation, we concluded the finds to be in situ. 
Table 3 Frequency of lithic artefact orientation

\begin{tabular}{lll}
\hline Orientation in $^{\circ}$ & Amount & Frequency (\%) \\
\hline $1-30$ & 599 & 9 \\
$31-60$ & 593 & 9 \\
$61-90$ & 576 & 9 \\
$91-120$ & 568 & 9 \\
$121-150$ & 517 & 8 \\
$151-180$ & 502 & 8 \\
$181-210$ & 481 & 7 \\
$211-240$ & 515 & 8 \\
$241-270$ & 575 & 9 \\
$271-300$ & 569 & 9 \\
$301-330$ & 562 & 8 \\
$331-360$ & 594 & 9 \\
$\boldsymbol{\Sigma}$ & 6651 & 100 \\
\hline
\end{tabular}

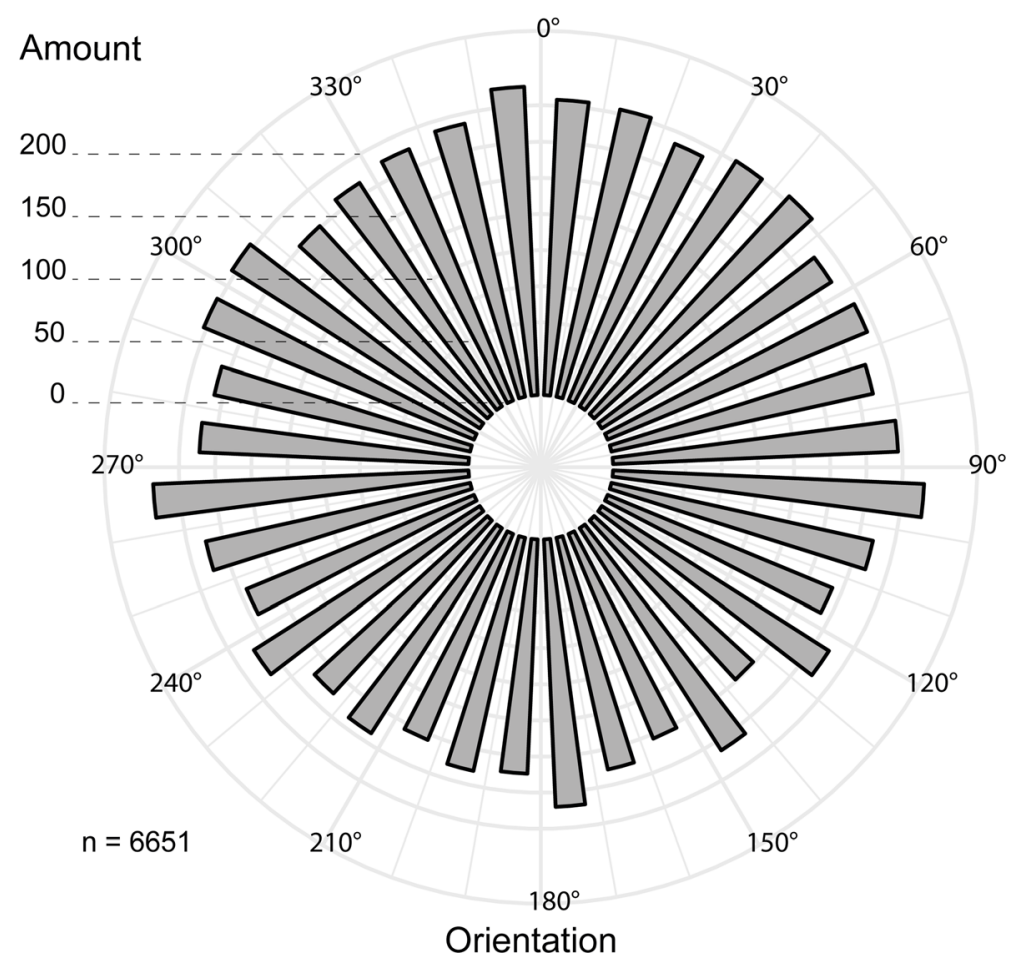

Fig. 4 Orientation of all tilted 2-point artefacts at Al-Ansab 1, AH 1 


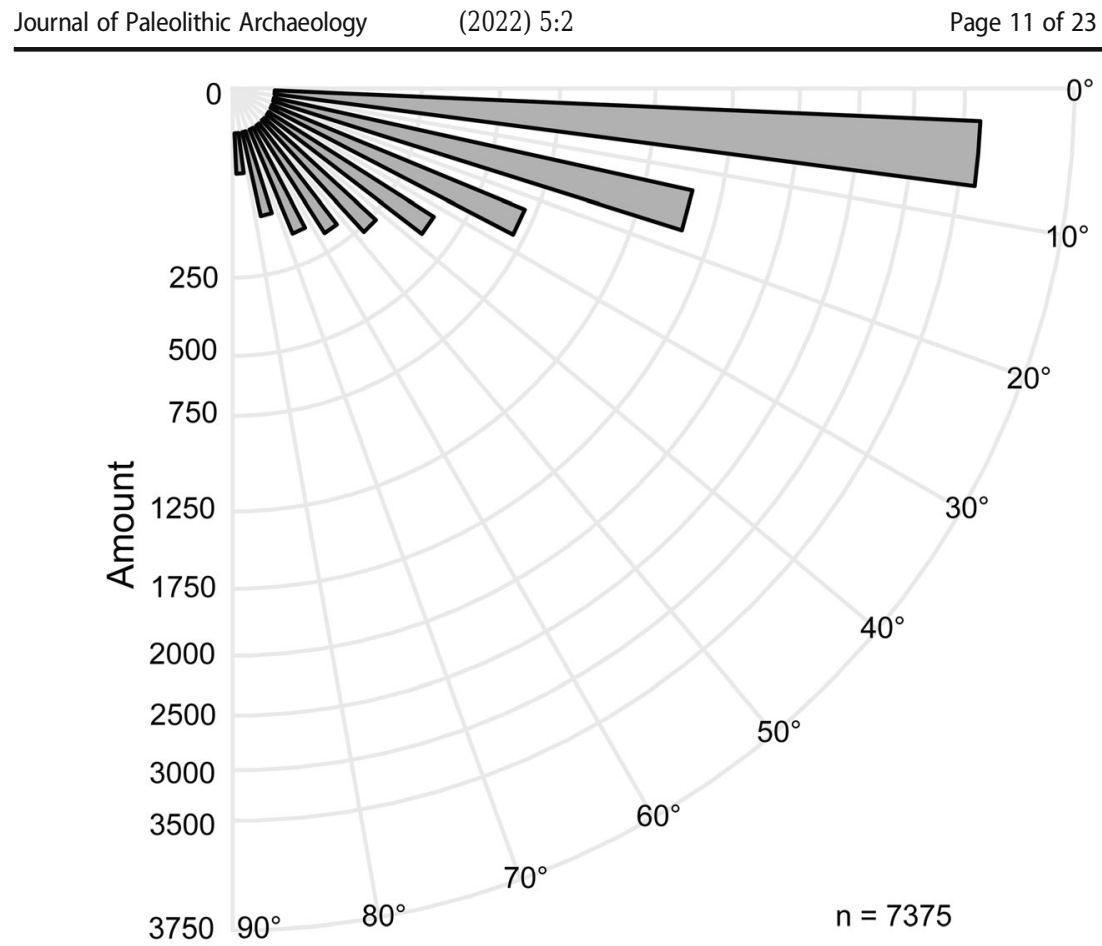

\section{Inclination}

Fig. 5 Inclination of all lithic 2-point artefacts at Al-Ansab 1, AH 1

\section{Distribution of Finds}

\section{Deviation from Median Artefact Elevation per Quarter Square Metre}

One issue was to determine the presence of pits in the occupation area which were not always visible to the naked eye. We used single-plotted artefacts (excavation

Table 4 Frequency of lithic artefact inclination

\begin{tabular}{lll}
\hline Inclination & $\boldsymbol{n}$ & Frequency (\%) \\
\hline $0-10$ & 3662 & 50 \\
$10-20$ & 1706 & 23 \\
$20-30$ & 750 & 10 \\
$30-40$ & 414 & 6 \\
$40-50$ & 276 & 4 \\
$50-60$ & 205 & 3 \\
$60-70$ & 179 & 2 \\
$70-80$ & 124 & 2 \\
$80-90$ & 59 & 1 \\
$\boldsymbol{\Sigma}$ & 7375 & 100 \\
\hline
\end{tabular}


campaigns 2015-2020) to analyse the deviation of finds from the median artefact elevation in the associated quarter square metre. Positive deviation from the median elevation is generally observable throughout the entire excavated area (Fig. 6a). Within the central part of the site, density of artefacts deviating from the median elevation is less expressed than in lateral sections. Pronounced positive deviation correlates to areas of high feature density. Low negative deviation clusters in areas of high feature density and increases towards the lateral sections (Fig. 6b). Lateral sections are also areas of greater feature density. High negative deviation can be observed throughout the excavated area in select cases (Fig. 6c). The median find elevation represents the general layout of the occupation layer, which differs from modern relief (Fig. 6d). Considering median elevation, the occupation layer tilts to a maximum of c. $6 \%$, whereas the modern slope tilts to a maximum of c. $25-30 \%$ in N-S direction. This corresponds to the idea that during occupation, the entire wadi had been filled with sediment to the site level (Parow-Souchon 2020, p. 128; Richter et al. 2020, p. 5).

\section{Artefact and Material Categories}

The comparison of areas with an LDI $\geq 1$ for different artefact categories reveals repeated clusters of different materials at similar locations. The reduction of information density by comparing selected categories allows to determine distinct clusters.

For this paper, we analysed the distribution of three main material categories (Table 2). The most abundant material category is the lithic artefacts. These can be further broken down into cores, débitage and modified pieces. Most of the faunal remains show a poor state of preservation. Both faunal objects and charcoal fragments $(>0.5 \mathrm{~cm})$ were documented in their three-dimensional position.

LDI clusters with a value $\geq 1$ represent the individual find categories. The distribution of flakes and blades/bladelets follow mainly the pattern of flint artefact clusters (Online Resources 1, 2 and 3). The comparison of LDI for flakes, blades/bladelets and chunks reveals a series of discrete clusters that overlay each other in large parts (Fig. 7a). The LDI of cores shows a similar, but less pronounced correlation pattern (Fig. 7b). Three characteristic tool types of the Early Ahmarian are El-Wad points, end-scrapers and burins (Belfer-Cohen and Goring-Morris 2017, p. 630). One LDI distribution represents all tool categories, as the number of artefacts within the individual classes is not sufficient to calculate significant LDIs (Fig. 7c).

We analysed the general distribution of materials (flint artefacts, faunal remains, charcoal and non-flint rocks) using the LDI $\geq 1$ (Online Resource 3). The main hotspot of flint artefacts shows up in the north-western corner of the excavated area. Smaller spots of increased find density are scattered more widely. The other material categories have a similar distribution pattern, with a slight offset from the flint artefact clusters.

The number of faunal remains does not allow conclusions on mass since their size can vary substantially. Several accumulations of faunal remains are scattered throughout the whole excavation area and show a tendency to correlate with flint artefact clusters (Online Resource 3b).

The non-flint rocks at Al-Ansab 1, AH 1, predominantly are unrounded stones. Since there are no larger rocks to be found in the otherwise homogeneous sands, these rocks probably are manuports. Charcoal density peaks in the northern part of the excavation area. Smaller clusters appear in other sections of the site (Online Resource 3d). 


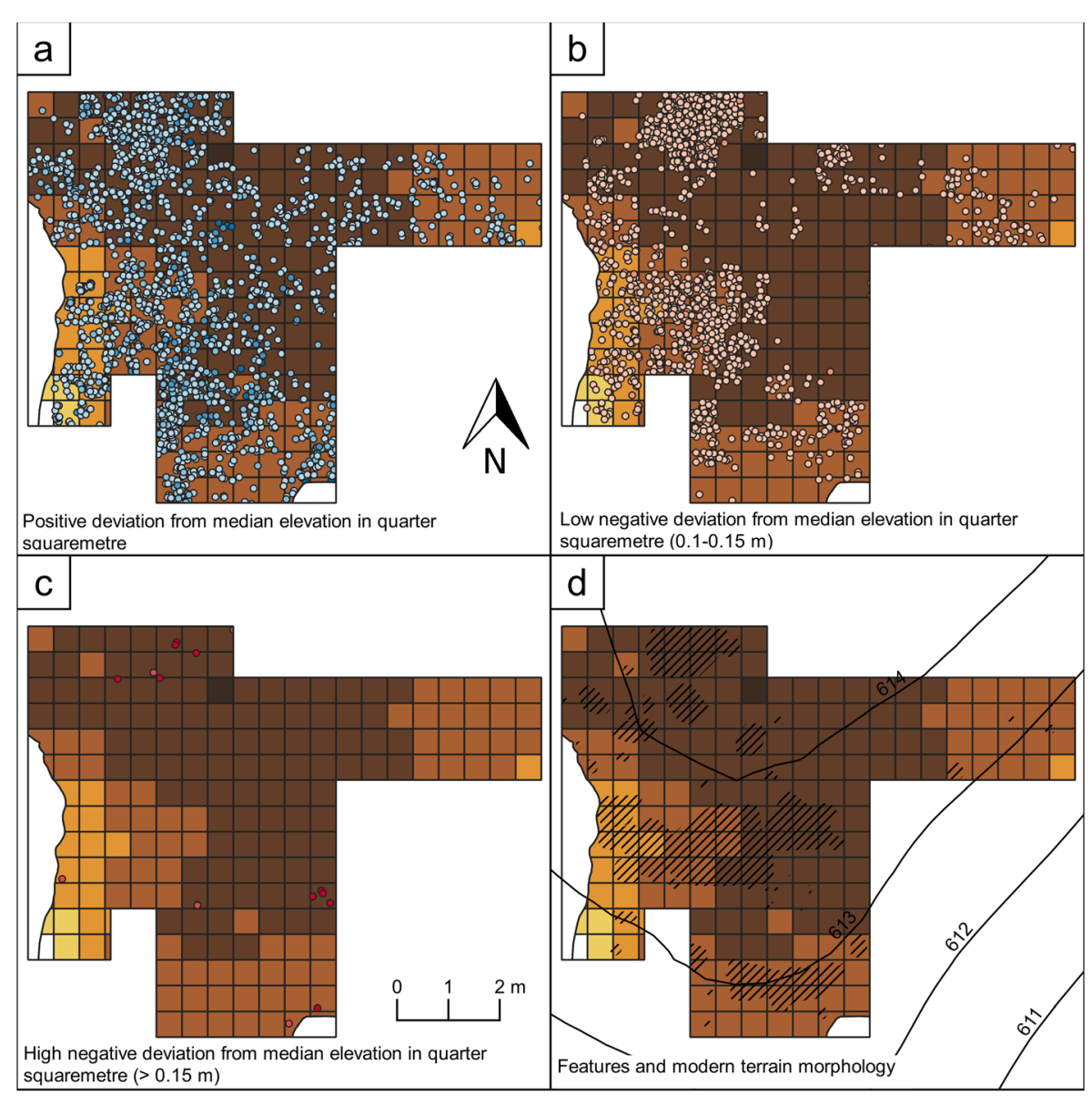

\section{Find Elevation vs Terrain Morphology}
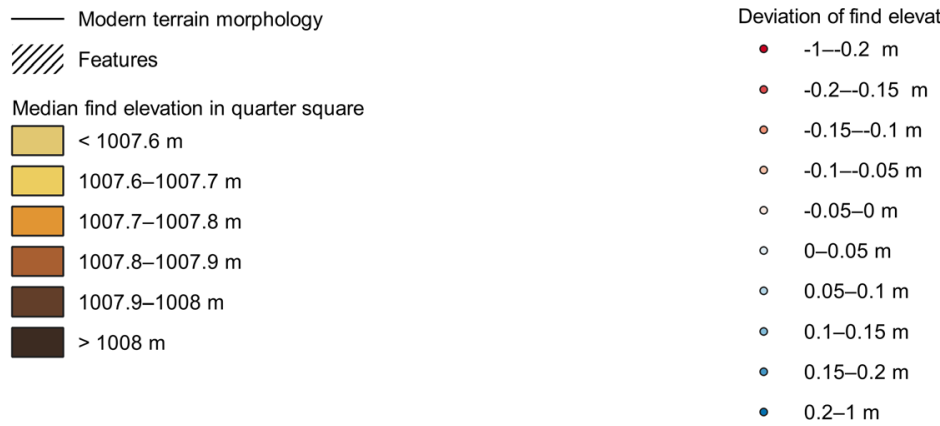

Fig. 6 Mapset of deviation of find elevation from the median find elevation in the associated quarter square metre. Figure section a shows all finds with a positive deviation of more than $5 \mathrm{~cm}$. b Finds with a negative deviation of 10 to $15 \mathrm{~cm}$. c Finds with a negative deviation of more than $15 \mathrm{~cm}$. d Median find elevation, features documented on site and modern surface morphology

The analysis of focal diversity shows that areas of high levels of diversity correlate with the presence of features as well as the distribution of burnt artefacts, charcoals and 


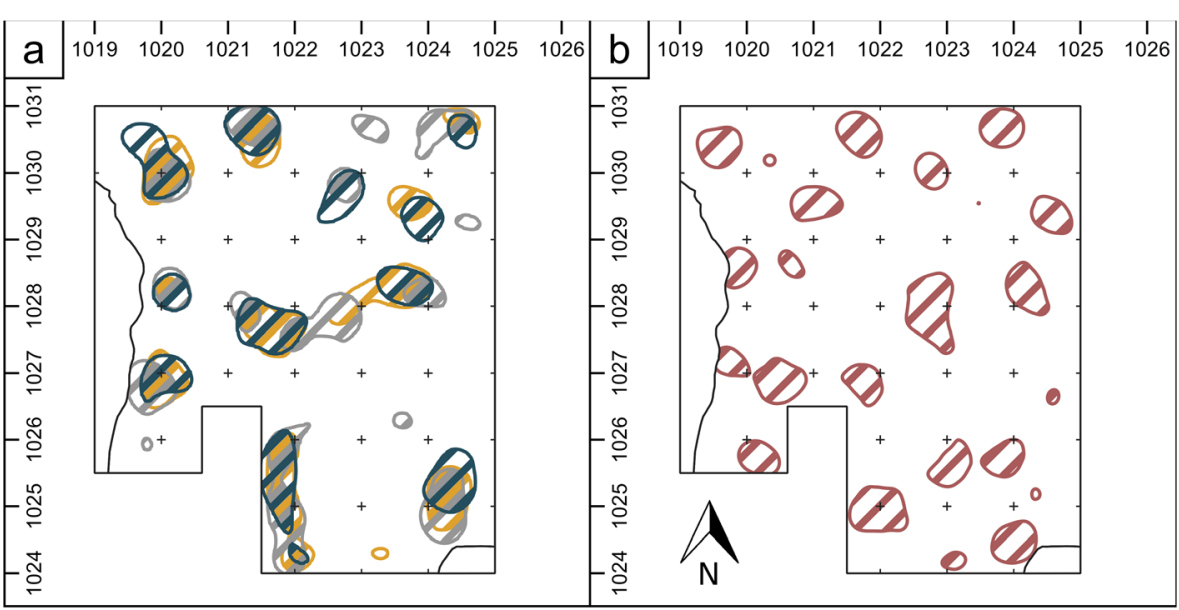

\section{$\mathbb{Z}$}

Blades/Bladelets, LDI $\geq 1$

Flakes, LDI $\geq 1$

Cores, $\mathrm{LDI} \geq 1$

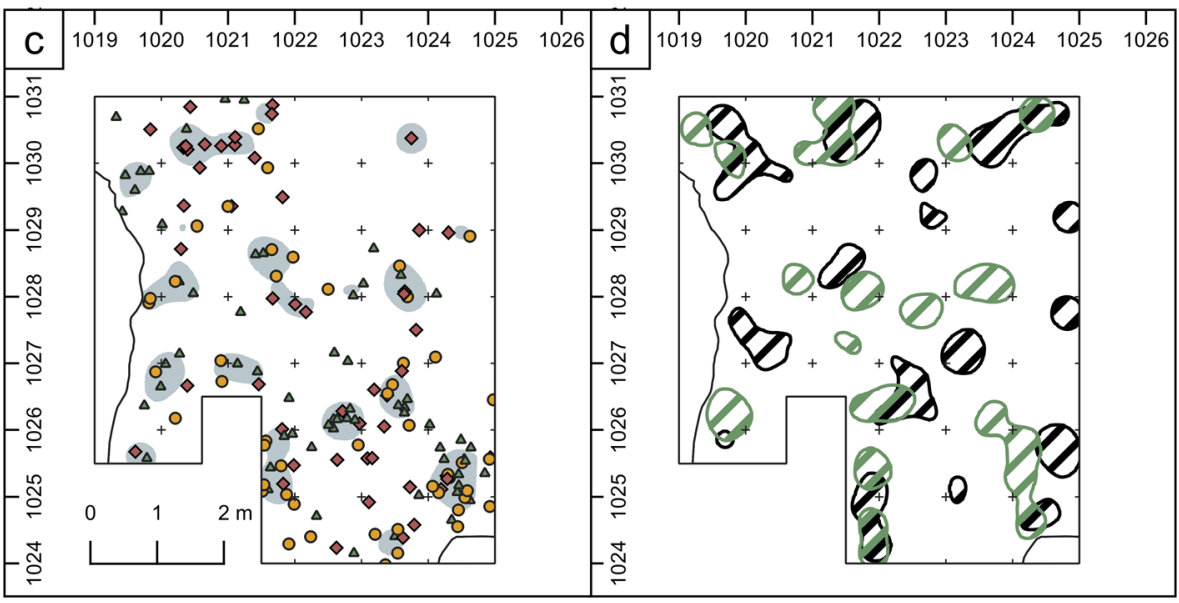

- Burin

Tools, LDI $\geq 1$

Fauna, LDI $\geq 1$

Charcoals, $\mathrm{LDI} \geq 1$

$\diamond \quad$ Endscraper

$\Delta \quad$ El-Wad Point

Fig. 7 a-d LDI maps of all single-plotted finds for the four main material categories at the LDI $\geq 1$ isoline (flint artefacts, charcoal, faunal remains and non-flint rocks)

faunal remains (Fig. 8). The values of diversity are typically high in areas where there are tools present.

\section{Fire Evidence}

During excavation, we repeatedly observed areas of darkened sediment. In some cases (e.g. features 37 and 45), red sands showed beneath several patches. We documented charcoal fragments larger than $5 \mathrm{~mm}$ by three-dimensional measurements. A plot of the LDI $\geq 1$ for charcoal fragments (Fig. 7d) suggests a spatial correlation with both the 


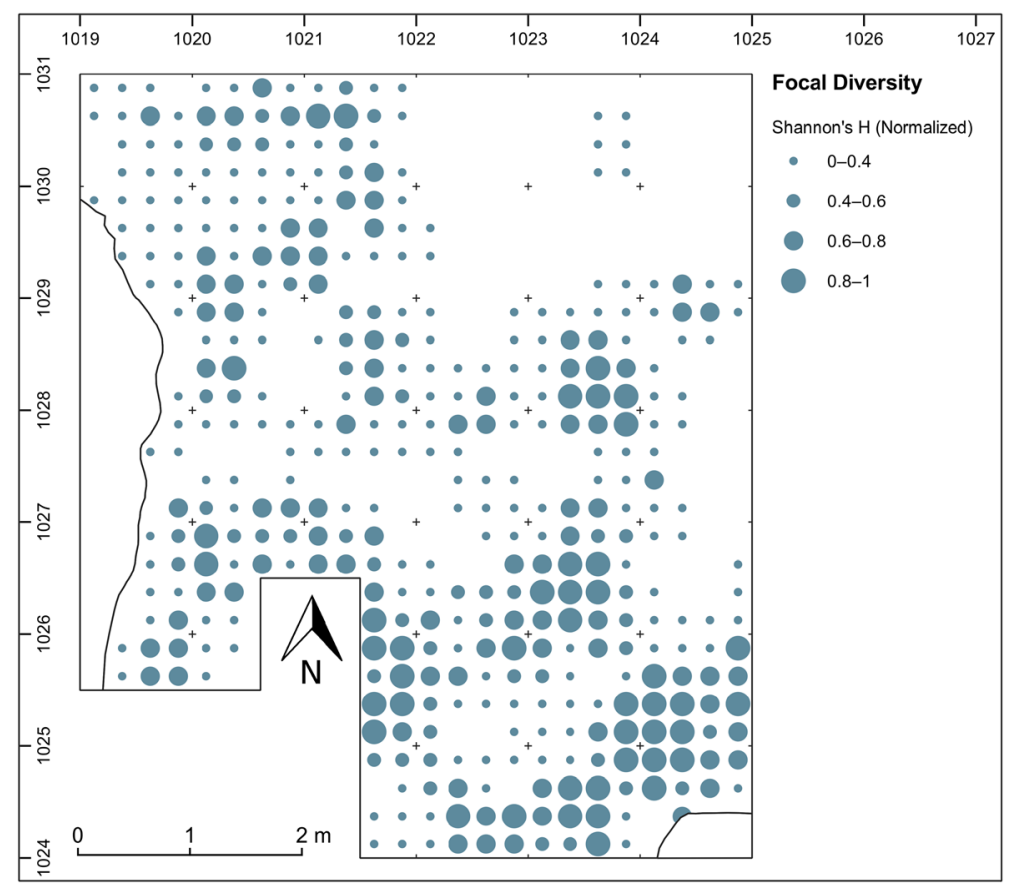

Fig. 8 Focal diversity of tools in a buffer of $35.35 \mathrm{~cm}$. The point size indicates the Shannon diversity of $\mathrm{H} / \mathrm{Hmax}$

features and other clusters of artefact categories. Burnt flint artefacts scatter in the vicinity of the charcoal concentrations and the patches of discoloured sediment (Online Resource 4).

\section{Discussion}

The orientation of artefacts at the site shows a limited tendency towards the North and North-East. In general, we believe this distribution not to represent mass flow events, which would have altered internal structuring of the site. If the find distribution would be affected by the modern southwards facing slope or by the confluence of the Wadi Al-Ansab and the Wadi Sabra, the finds would also show an orientation to the South, which is not the case. Orientation trends in AH 1 are marginal when compared to other assemblages with a clear re-orientation by mass flow events (McPherron 2005, 2018). Charcoal density also correlates to the patches of darkened sediment and correlates well with clusters of burnt flint artefacts (Online Resource 4).

We analysed the deviation of single-plotted artefacts from the median elevation in each quarter square metre to the presence of pits. Substantial negative deviation of artefact elevation strongly correlates with the observed darkened sediment features. We see these negative deviations as the result of artefact discard during occupation. The combustion features were depressions in the sediments which were filled with artefact discard of various categories. 
The different find categories show a clear internal structuring at the site of Al-Ansab 1, AH 1. The comparison of the main débitage classes (flakes, blades/bladelets) reveals zones of pronounced flint knapping activity. The distribution of cores in the site also shows a correlation with clusters of débitage. While blank concentrations tend to cluster close to one another, cores are often set off slightly (Fig. 9a). This pattern is equivalent to drop and toss zones (Binford 1978, p. 345), where the débitage is dropping in the process of core reduction whereas a depleted core is discarded elsewhere. By drawing the minimum bounding circles around both groups (débitage, cores), the hub distance can be used to relate toss zones to the nearest drop zone (Fig. 9b). This way, we divided the excavated area into 12 activity centres. Here, activity centres are understood as non-discrete areas of relatively higher occupational intensity. These areas are not separated by explicit boundaries but rather reflect spaces of increased find density relative to their vicinity. The activity centres also frequently coincide with other material categories such as charcoals and faunal remains (Fig. 7d).

Just like the other distributions, the focal diversity values of toolset composition show a clustering of diverse areas in the vicinity of activity centres (Fig. 8). However, while the other artefact classes repeatedly correlate with all activity centres, tools remain almost absent in the north-western corner of the excavation area (zones 1, 4 and 5). The inhabitants of the site discarded a variety of tools at almost every location (Fig. 8). If the discarded tools are the remnants of on-site activities and not the traces of rehafting and retooling, this would represent a low specialisation of tasks in most of the activity centres. In the north-western corner, only core reduction and discard of faunal elements in the context of a charcoal feature could be observed while no tools were discarded, here.

It must be pointed out that the activity centres, which could be reconstructed in this article, also correlate with the patches of darkened sediment, which we observed during excavation. While determining the presence of combustion features by spatial analysis remains difficult (Sobkowiak-Tabaka and Diachenko 2019), at Al-Ansab 1, AH 1, there are several points which suggest that the darkened sediments are the traces of combustion features. The patches coincide with concentrations of larger charcoal fragments $(>$ $0.5 \mathrm{~cm}$ ) and burnt flint artefacts. Such conditions occur at several Early Ahmarian sites (Abu Noshra I and II (Becker 2003); Boker A (Monigal 2003); Nahal Nizzana XIII (Davidzon and Goring-Morris 2003); Lagama VI-VIII and XVI (Bar-Yosef and Belfer 1977a)), but with different levels of intensity. At Abu Noshra I, the combustion feature is associated with burnt bones and teeth of an onager. This places such patches in the context of roasting hunted prey (Becker 2003). Burnt flint artefacts indicate firing temperatures exceeding $300{ }^{\circ} \mathrm{C}$ pointing towards the anthropogenic origin of such fires (Frick et al. 2012; Sobkowiak-Tabaka and Diachenko 2019; Stahlschmidt et al. 2015).

The combustion features in AH 1 seem to be associated with a discrete and reoccurring set of attributes (core reduction, rehafting and retooling and processing of faunal elements). In their vicinity, various activities were carried out. Particularly, the reduction of cores played an important role at Al-Ansab 1, AH 1. Almost systematically, the patches show discrete locations of core reduction and core discard, the use of organic resources and the combustion of fuels. This is comparable to drop and toss zones (Binford 1978, 1983). The relationship between lithic scatters and combustion features in Early Ahmarian sites is generally close with a spread of artefacts outside the core area (Becker 2003; Bar-Yosef and Belfer 1977b; Davidzon and Goring-Morris 


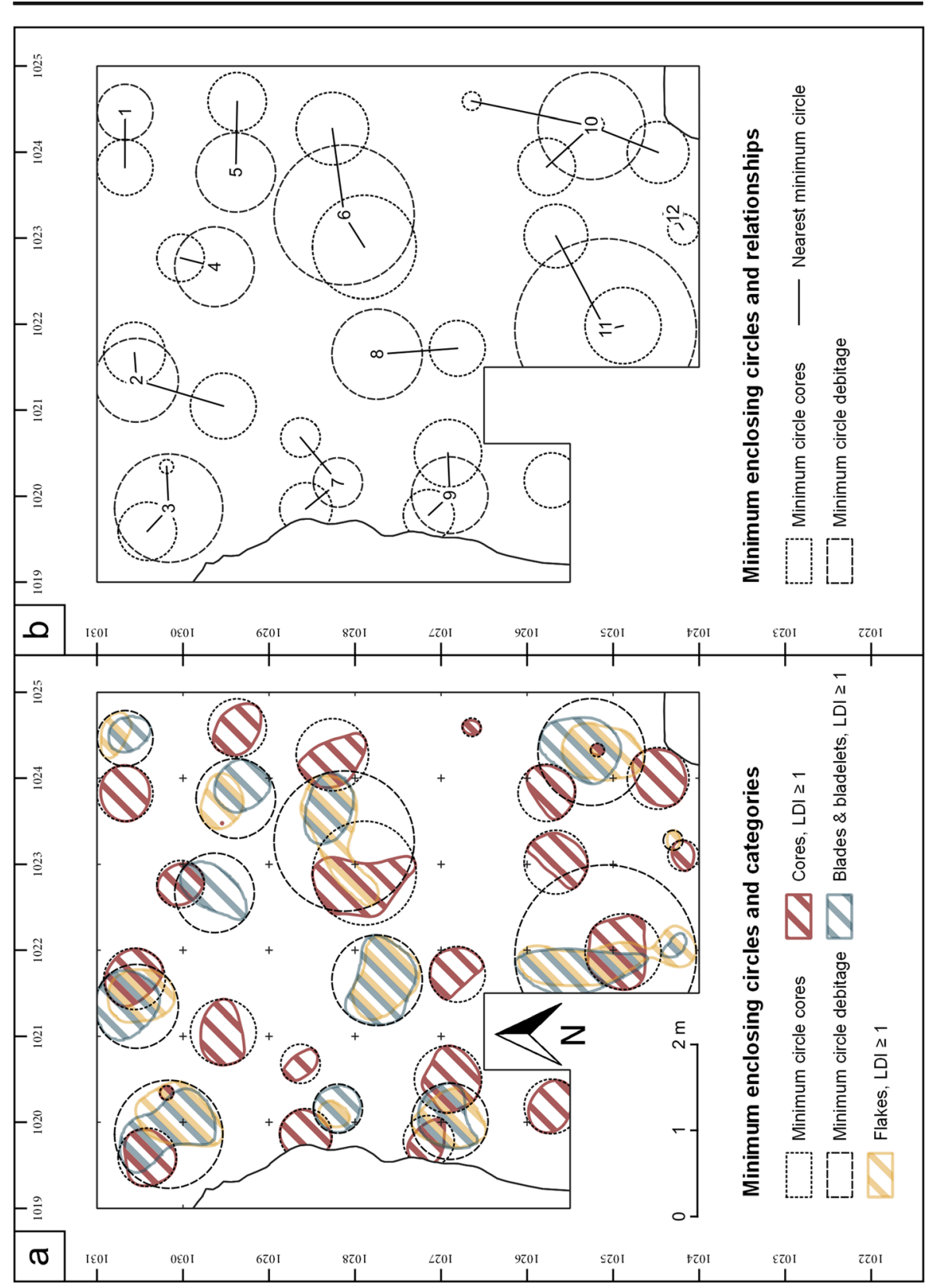

Fig. 9 Activity centres at Al-Ansab 1, AH 1, based on the LDI distribution of blade(lets), flakes and cores. Section a shows the minimum bounding circles around the main categories of the debitage as dashed line, whereas the minimum enclosing circle of the core LDI is illustrated by a dotted line. Section b connects the nearest circles of debitage and cores with each other, generating 12 different activity centres

2003; Marks 1983; Coinman 2009). Refitting analyses at different sites indicate that core reduction activities occur in an area of variable size around the hearths (Table 5). At Nahal Nizzana XIII, refitted flint artefacts scatter over an area of c. $12 \mathrm{~m}^{2}$ in relation 
Table 5 Characteristics of hearth-related find distributions in other spatially analysed sites of the Early Ahmarian

\begin{tabular}{lllll}
\hline Site & Hearth & Characteristics & Spatially discrete tasks & Spatial extent $\mathbf{~}^{\mathbf{2}} \mathbf{)}$ \\
\hline Abu Noshra I & 4 & Ash concentrations & None & $14-16$ \\
Abu Noshra II & 15 & Ash concentrations & None & $\sim 25$ \\
Boker A & 1 & - & None & $\sim 13$ \\
Boker BE, III & 5 & Ash concentrations & - & $\sim 31$ \\
Boker BE, IV & 5 & Ash concentrations & - & $\sim 15$ \\
Lagama VII & 2 & Ash concentrations & None & $\sim 20$ \\
Lagama XVI & 1 & Ash concentration & None & 4 \\
Nahal Nizzana XIII & 1 & Indirect (burnt slices) & None & $\sim 12$ \\
Tha'lab al-Buhayra C & $>3$ & Ash concentration & None & $\sim 19$ \\
\hline
\end{tabular}

a The spatial extent describes the area of core exploitation related to hearths

to a single hearth (Davidzon and Goring-Morris 2003). Rather similar examples can be found at Boker A (Monigal 2003). At Abu Noshra II and Lagama VII, the débitage covers areas between 20 and $25 \mathrm{~m}^{2}$ but seems to be related to several combustion features (Bar-Yosef and Belfer 1977b; Becker 2003). Such a situation also occurs at Boker BE (Marks 1983). At Abu Noshra I and II, as well as the Lagama sites, artefact density maxima closely relate to the hearths, while at Nahal Nizzana XIII, densities seem to be less tethered to the fireplace. However, the fireplace is determined only indirectly at Nahal Nizzana XIII.

The distribution of flint artefacts, bone fragments and charcoal patches in $\mathrm{AH} 1$ suggests a repeated and non-specialised occupation of the site. Essentially, the huntergatherers executed all tasks (core reduction, retooling, rehafting, processing of hunted prey) on site, indicating no expressed logistical component in the local settlement system. However, at Abu Noshra IV, a site related to the contemporaneous location of Abu Noshra I could be observed at a distance of only c. $200 \mathrm{~m}$ (Becker 2003). This shows that activities can spread over a large local area around an Early Ahmarian site.

The absence of internal task specialisation of the site of Al-Ansab 1, AH 1, shows a situation which also could be observed at several Early Ahmarian sites (Becker 2003; BarYosef and Belfer 1977b; Coinman 2009; Davidzon and Goring-Morris 2003; Monigal 2003). Abu Noshra II, Boker A, Tha'lab al-Buhayra C and the Lagama sites show no internal functional structuring of the sites which was substantiated by refitting of flint artefacts (Becker 2003, p. 148; Bar-Yosef and Belfer 1977b; Monigal 2003). Site locations with a comparable pattern of artefact concentrations can be documented well outside the spatial frame of the Early Ahmarian. For sites of the Negev Desert, Marks and Friedel (1977, p. 153) postulated a highmobility spatial behaviour equivalent to Binford's concept of residential mobility (Kelly 1992; Binford 1980). For the southern Sinai Peninsula, a relatively static settlement system was proposed (Phillips and Saca 2003, p. 104). Phillips (1987a, b) argued that the prevailing ecological mosaic of the sites in the southern Sinai promoted the possibility for a more stationary lifestyle tethered to the rich microhabitats of the waterbodies in this region. However, this is contrasted by Becker's interpretation of the intra-site find distribution at Abu Noshra II as being the result of a relatively mobile settlement behaviour (2003). However, 
at Tha'lab al-Buhayra, Coinman (2009) suggests a task-specialised site, which could indicate a logistical component to the settlement system. We have to assume varying systems during the annual circle of the Early Ahmarian hunter-gatherer. Furthermore, highly mobile models such as the circulating pattern seem to be consensus for early anatomically modern humans in the Levant (Marks and Friedel 1977; Lieberman 1993; Wallace and Shea 2006; Belfer-Cohen and Goring-Morris 2018). The site of Al-Ansab 1, AH 1, must be seen as the result of expressed residential mobility, too (Richter et al. 2020). However, a rich microhabitat comparable to the sites in Wadi Feiran (Phillips and Saca 2003), Boker A (Monigal 2003) or Qadesh Barnea (Gilead and Bar-Yosef 1993) could be observed at Al-Ansab 1, AH 1, too (Richter et al. 2020; Parow-Souchon 2020; Sauer and Schoenenberg 2021).

The chronological depth within and between these activity centres remains a matter of discussion. Since many of the areas are relatively discrete and not showing any signs of overlap (Fig. 9), it could be argued that these have been relatively contemporaneous, as if the individuals avoided an already littered spot or sat down at the exact same one. In other cases (area 6 or 11), the opposite might have been the case. Bigger circles indicate a greater dispersion of artefacts. One possible interpretation could be that an earlier occupation was not visible anymore and superimposed by a later one. It should be mentioned that the LDI tends to overemphasise discreteness. Ultimately, artefact refits will be able to shed light on these kinds of research questions.

The site of Al-Ansab 1, AH 1, essentially shows the repeated use of the location for a variety of different tasks in the principle of "site-provisioning" (Hovers 2017, p. 597). The composition and size of the flint artefact assemblage suggests the extensive and generous use of the local raw material. This gives the site a workshop character with a relatively high artefact density, given the ephemeral nature of the occupations. Faunal resources, particularly gazelles, were used as well (Parow-Souchon 2020). This correlates with other Early Ahmarian sites throughout the region, where Gazella sp. belongs to the primarily exploited game. The Wadi Sabra forms a corridor, linking the Transjordanian Highlands with the Wadi Araba, and also is a corridor of mobility for gazelles between the two habitats (Sauer and Schoenenberg 2021). The El-Wad points, which were scattered throughout the excavated area, correspond to the idea of discarded gear (Binford 1979, p. 267) and the hunting of gazelle, which we identified in the faunal material. While other tool types are more likely to represent on-site activities such as processing of prey, the El-Wad points represent rehafting activities.

The repeated clustering of similar find categories as well as the low degree of spatial organisation and site modification indicates short residential stays, combined with an opportunistic subsistence strategy. In contrast, a lower level of mobility leads to a higher segmentation of activities, making an internal differentiation of the site more probable. A logistical or food-to-camp provisioning strategy would equally lead to a longer occupational duration in the basecamp and therefore to a higher complexity in site organisation (Kelly 1992, p. 56; Henry 2002, pp. 130-132; Panja 2003, pp. 110112). The latter could not be observed at Al-Ansab 1 ( $\mathrm{AH} 1)$.

\section{Conclusion}

The site of Al-Ansab 1, AH 1, provides a great number of artefacts from different material categories typical for Early Ahmarian sites (Belfer-Cohen and Goring-Morris 
2017). Among them are a large amount of flint artefacts, tools, ochre, seashell as well as unmodified grinding stones. Analysis showed that the archaeological material at the site was not subject to substantial displacement by post-depositional processes. Also, the different flint artefact classes (e.g. cores, flakes, blades or burnt flint objects) cluster in relatively discrete groups and show no indication of post-depositional intermixture. The thickness of the find layer varies in some locations which could be linked to the presence of pits during the time of occupation. This is best exemplified by the feature 59 in the North of the excavated area (Fig. 3).

There is no indication for task specialisation in the 12 activity centres of the site. Repeatedly, blank production was executed in relatively discrete clusters, starting at the decortication of raw nodules and ending with the discard of exploited cores. These activity centres typically associate to a combustion feature and a scatter of faunal remains. It is difficult to discern, whether activity centres overlap at Al-Ansab 1, AH 1, or whether they are as discrete and mutually exclusive as they appear. Density distributions often are closely linked to hearths (Becker 2003; Bar-Yosef and Belfer 1977b; Coinman 2009). Refitted debitage scatters over larger areas at other Early Ahmarian sites (Davidzon and Goring-Morris 2003; Becker 2003; Bar-Yosef and Belfer 1977b), suggesting that at Al-Ansab 1, AH 1, the picture might be less discrete. The true relationships between the different activity centres can only be decoded by future refits of flint artefacts. Compared to other sites within the Early Ahmarian (see Becker 2003, p. 148), the pattern reflects a high level of mobility (Kelly 1992, p. 56) of comparably small bands of hunter-gatherers who repeatedly visited the location for the exploitation of raw material, for rehafting, hunting and processing of prey.

Supplementary Information The online version contains supplementary material available at https://doi.org/ 10.1007/s41982-021-00103-7.

Acknowledgements The results presented here are the outcome of research conducted in the Collaborative Research Centre 806 "Our Way to Europe" (funded by the Deutsche Forschungsgemeinschaft (DFG, German Research Foundation); project number 57444011) based at the University of Cologne. We thank the Department of Antiquities (Amman/Jordan) for granting the excavation permits and Prof. Maysoon Al Nahar from the University of Jordan, Amman, for supporting logistics and student participation.

Code Availability Not applicable

Author Contribution All authors contributed to the study conception and design. Material preparation, data collection and analysis were performed by Jonathan Schoenenberg, M.A and Dr. Florian Sauer. The first draft of the manuscript was written by Jonathan Schoenenberg, M.A. and Dr. Florian Sauer, and all authors commented on previous versions of the manuscript. All authors read and approved the final manuscript.

Funding Open Access funding enabled and organized by Projekt DEAL. This research was funded by the Deutsche Forschungsgemeinschaft (DFG) in the Collaborative Research Centre 806 "Our Way to Europe" (Project number 57444011) based at the University of Cologne.

Data Availability The datasets generated during and/or analysed during the current study are available from the corresponding author on reasonable request.

\section{Declarations}

Competing Interests The authors declare no competing interests. 
Open Access This article is licensed under a Creative Commons Attribution 4.0 International License, which permits use, sharing, adaptation, distribution and reproduction in any medium or format, as long as you give appropriate credit to the original author(s) and the source, provide a link to the Creative Commons licence, and indicate if changes were made. The images or other third party material in this article are included in the article's Creative Commons licence, unless indicated otherwise in a credit line to the material. If material is not included in the article's Creative Commons licence and your intended use is not permitted by statutory regulation or exceeds the permitted use, you will need to obtain permission directly from the copyright holder. To view a copy of this licence, visit http://creativecommons.org/licenses/by/4.0/.

\section{References}

Agostinelli, C., \& Lund, U. (2017). R package circular: Circular statistics (version 0.4-93). https://r-forge.rproject.org/projects/circular/.

Alex, B., Barzilai, O., Hershkovitz, I., Marder, O., Berna, F., Caracuta, V., et al. (2017). Radiocarbon chronology of Manot Cave, Israel and Upper Paleolithic dispersals. Science Advances, 3(11), e1701450.

Arsham, H. (1988). Kuiper's P-value as a measuring tool and decision procedure for the goodness-of-fit test. Journal of Applied Statistics, 15(2), 131-135.

Bar-Yosef, O., \& Belfer, A. (1977a). The Lagama industry. Prehistoric Investigations in Gebel Maghara, Northern Sinai. Qedem, 7, 42-85.

Bar-Yosef, O., \& Belfer, A. (1977b). The Lagaman industry. In O. Bar-Yosef \& J. Phillips (Eds.), Prehistoric investigations in Gebel Maghara, Northern Sinai (pp. 42-84). Hebrew University of Jerusalem.

Becker, M. S. (2003). Spatial patterning in the Upper Palaeolithic: A perspective from the Abu Noshra sites. In A. Belfer-Cohen \& N. Goring-Morris (Eds.), More than meets the eye: Studies on Upper Palaeolithic diversity in the Near East (pp. 134-150). Oxbow Books.

Belfer-Cohen, A., \& Goring-Morris, N. (2017). The Upper Palaeolithic in Cisjordan. In Y. Enzel \& O. BarYosef (Eds.), Quaternary of the Levante (pp. 627-638). Cambridge Univ. Press.

Belfer-Cohen, A., \& Goring-Morris, N. (2018). An anthropological review of the Upper Paleolithic in the Southern Levant. In A. Yasur-Landau, E. H. Cline, \& Y. M. Rowan (Eds.), The social archaeology of the Levant: From prehistory to the present (pp. 29-46). Cambridge University Press.

Bertrams, M. (2013). Late Quaternary landscape evolution in the Wadi Sabra (Jordan) based on sedimentological and geochemical investigations. Geographisches Institut der RWTH.

Bertrams, M. (2015). Geography and landscape evolution of the Wadi Sabra and adjacent areas. In D. Schyle \& J. Richter (Eds.), Pleistocene archaeology of the Petra area in Jordan (pp. 9-42). Rahden/Westf.: Verlag Marie Leidorf GmbH.

Bertrams, M., Protze, J., Löhrer, R., Schyle, D., Richter, J., Hilgers, A., et al. (2012). Multiple environmental change at the time of the Modern Human passage through the Middle East: First results from geoarcheological investigations on Upper Pleistocene sediments in the Wadi Sabra (Jordan). Quaternary International, 274, 55-72.

Bertrams, M., Protze, J., Eckmeier, E., \& Lehmkuhl, F. (2014). A geochemical approach on reconstructing Upper Pleistocene environmental conditions from wadi deposits - An example from the Wadi Sabra (Jordan). Zeitschrift für Geomorphologie, Supplementary Issues, 58(1), 51-80.

Binford, L. R. (1978). Dimensional analysis of behavior and site structure: Learning from an Eskimo hunting stand. American Antiquity, 43(3), 330-361.

Binford, L. R. (1979). Organization and formation processes: Looking at curated technologies. Journal of Anthropological Research, 35(3), 255-273.

Binford, L. R. (1980). Willow smoke and dogs' tails: Hunter-gatherer settlement systems and archaeological site formation. American Antiquity, 45(2), 4-20.

Binford, L. R. (1983). In pursuit of the past: Decoding the archaeological record. University of California Press.

Coinman, N. (2009). A tale of two sites: Pleistocene hunter-foragers of the Jordanian Eastern Deserts. Studies in the History and Archaeology of Jordan, 10, 347-362.

Davidzon, A., \& Goring-Morris, A. N. (2003). Sealed in stone: The Upper Palaeolithic Early Ahmarian knapping method in the light of refitting studies at Nahal Nizzana XIII, Western Negev, Israel. In A. N. Goring-Morris \& A. Belfer-Cohen (Eds.), More than meets the eye: Studies on Upper Palaeolithic diversity in the Near East (pp. 75-205). Oxbow Books. 
De Reu, J., Bourgeois, J., Bats, M., Zwertvaegher, A., Gelorini, V., De Smedt, P., et al. (2013). Application of the topographic position index to heterogeneous landscapes. Geomorphology, 186, 39-49.

Frick, J. A., Hoyer, C. T., Herkert, K., \& Floss, H. (2012). Comparative heating experiments on flint from the Côte Chalonnaise, Burgundy, France. Anthropologie, 50(3), 295-322.

Gilead, I., \& Bar-Yosef, O. (1993). Early Upper Paleolithic sites in the Qadesh Barnea area, NE Sinai. Journal of Field Archaeology, 20(3), 265-280.

Goring-Morris, A. N. (1995). Upper Paleolithic occupation of the Ein Qadis area on the Sinai/Negev border. Atiqot, 27, 1-14.

Henry, D. O. (2002). Intrasite spatial patterns and behavioral modernity. Neandertals and modern humans in Western Asia (pp. 127-142). New York: Springer.

Hershkovitz, I., Marder, O., Ayalon, A., Bar-Matthews, M., Yasur, G., Boaretto, E., et al. (2015). Levantine cranium from Manot Cave (Israel) foreshadows the first European modern humans. Nature, 520(7546), 216-219.

Hovers, E. (2017). Middle Palaeolithic Open-Air Sites. In Y. Enzel \& O. Bar-Yosef (Eds.), Quaternary of the Levant: Environments, climate change, and humans (pp. 593-600). Cambridge University Press.

Hublin, J.-J. (2015). The modern human colonization of western Eurasia: When and where? Quaternary Science Reviews, 118, 194-210.

Hussain, S. T. (2015). Betwixt seriality and sortiment: Rethinking Early Ahmarian blade technology in AlAnsab 1. In D. Schyle \& J. Richter (Eds.), Pleistocene archaeology of the Petra area in Jordan (pp. 131148). Rahden/Westf.: Verlag Marie Leidorf GmbH.

Jones, M., Marks, A., \& Kaufman, D. (1983). Boker: The artifacts. In A. Marks (Ed.), The Avdat/Aqev area, part 3 (pp. 283-329). Department of Anthropology, Southern Methodist University.

Kelly, R. L. (1992). Mobility/sedentism: Concepts, archaeological measures, and effects. Annual Review of Anthropology, 21(1), 43-66.

Klasen, N., Hilgers, A., Schmidt, C., Bertrams, M., Schyle, D., Lehmkuhl, F., et al. (2013). Optical dating of sediments in Wadi Sabra (SW Jordan). Quaternary Geochronology, 18, 9-16.

Li, L., Lin, S. C., Peng, F., Patania, I., Guo, J., Wang, H., et al. (2020). Simulating the impact of ground surface morphology on archaeological orientation patterning. Journal of Archaeological Science, 126, 105310 .

Lieberman, D. E. (1993). The rise and fall of seasonal mobility among hunter-gatherers: The case of the Southern Levant. Current Anthropology, 34(5), 599-631.

Löhrer, R., Bertrams, M., Eckmeier, E., Protze, J., \& Lehmkuhl, F. (2013). Mapping the distribution of weathered Pleistocene wadi deposits in Southern Jordan using ASTER, SPOT-5 data and laboratory spectroscopic analysis. Catena, 107, 57-70.

Marks, A. (Ed.). (1983). Prehistory and paleoenvironments in the Central Negev, Israel. Southern Methodist University.

Marks, A., \& Friedel, D. (1977). Prehistoric settlement patterns in the Avdat/Aqev area. In A. Marks (Ed.), Prehistory and paleoenvironments in the Central Negev, Israel (pp. 131-158). Department of Archaeology.

McPherron, S. J. P. (2005). Artifact orientations and site formation processes from total station proveniences. Journal of Archaeological Science, 32, 1003-1014.

McPherron, S. J. P. (2018). Additional statistical and graphical methods for analyzing site formation processes using artifact orientations. PLoS One, 13(1), 1-21.

Miebach, A., Stolzenberger, S., Wacker, L., Hense, A., \& Litt, T. (2019). A new Dead Sea pollen record reveals the last glacial paleoenvironment of the Southern Levant. Quaternary Science Reviews, 214, 98116. https://doi.org/10.1016/j.quascirev.2019.04.033

Monigal, K. (2003). Technology, economy and mobility at the beginning of the Levantine Upper Palaeolithic. In A. N. Goring-Morris \& A. Belfer-Cohen (Eds.), More than meets the eye: Studies on Upper Palaeolithic diversity in the Near East (pp. 118-133). Oxbow Books.

Panja, S. (2003). Mobility strategies and site structure: A case study of Inamgaon. Journal of Anthropological Archaeology, 22(2), 105-125.

Parow-Souchon, H. (2020). The Wadi Sabra (Jordan). Rahden/Westfalen: Verlag Marie Leidorf GmbH.

Phillips, J. (1987a). Sinai during the Paleolithic: The early periods. Prehistory of arid North Africa: Essays in honor of Fred Wendorf, 105-121.

Phillips, J. (1987b). Upper Paleolithic hunter-gatherers in the Wadi Feiran, southern Sinai. In O. Soffer (Ed.), The Pleistocene Old World (pp. 169-182). Springer.

Phillips, J., \& Saca, I. N. (2003). Variability and change in the Early Upper Palaeolithic of the Levant. In A. Belfer-Cohen \& N. Goring-Morris (Eds.), More than meets the eye: Studies on Upper Palaeolithic diversity in the Near East (pp. 95-105). Oxbow Books. 
QGIS, D. T (2020). QGIS geographic information system. Open Source Geospatial Foundation.

$\mathrm{R}$ Core Team. (2019). R: A language and environment for statistical computing. R Foundation for Statistical Computing.

Richter, J., Schyle, D., \& Wolter, T. (2015). The CRC 806 “Our Way to Europe" - Field campaigns into the archaeology of Wadi Sabra from 2008 to 2013. In D. Schyle \& J. Richter (Eds.), Pleistocene archaeology of the Petra area in Jordan (pp. 9-42). Rahden/Westf.: Verlag Marie Leidorf GmbH.

Richter, J., Litt, T., Lehmkuhl, F., Hense, A., Hauck, T. C., Leder, D. F., et al. (2020). Al-Ansab and the Dead Sea: Mid-MIS 3 archaeology and environment of the Early Ahmarian population of the Levantine corridor. PLoS One, 15(10), e0239968.

Sauer, F., \& Schoenenberg, J. (2021). Gazelle hunting strategies in the Early Ahmarian: Close-range visuospatial characteristics of site locations indicate spatially focused hunting strategies on Gazella sp. during the Early Ahmarian. Journal of Paleolithic Archeology.

Schyle, D. (2015a). The Ahmarian site of Al-Ansab 1. In D. Schyle \& J. Richter (Eds.), Pleistocene archaeology of the Petra area in Jordan (pp. 91-129). Rahden/Westf.: Verlag Marie Leidorf GmbH.

Schyle, D. (2015b). Pleistocene deposits and archaeological sites. In D. Schyle \& J. Richter (Eds.), Pleistocene archaeology of the Petra area in Jordan (pp. 51-54). Rahden/Westf.: Verlag Marie leidorf GmbH.

Schyle, D. (2015c). The Upper Paleolithic sequence of the Petra area and the Upper Paleolithic of the Levante. In D. Schyle \& J. Richter (Eds.), Pleistocene archaeology of the Petra area in Jordan (pp. 360-393). Rahden/Westf.: Verlag Marie Leidorf GmbH.

Shannon, C. (1949). The mathematical theory of communication. The University of Illinois Press.

Sobkowiak-Tabaka, I., \& Diachenko, A. (2019). Fire and "noise" in late Paleolithic camps: An investigation of issues in locating hearths. Journal of Paleolithic Archaeology, 3, 1-16.

Stahlschmidt, M. C., Miller, C. E., Ligouis, B., Hambach, U., Goldberg, P., Berna, F., et al. (2015). On the evidence for human use and control of fire at Schöningen. Journal of Human Evolution, 89, 181-201.

Wallace, I. J., \& Shea, J. J. (2006). Mobility patterns and core technologies in the Middle Paleolithic of the Levant. Journal of Archaeological Science, 33(9), 1293-1309.

Wilson, J. P., \& Gallant, J. C. (2000). Primary topographic attributes. In J. P. Wilson \& J. C. Gallant (Eds.), Terrain analysis: Principles and applications (pp. 51-85). John Wiley \& Sons.

Publisher's Note Springer Nature remains neutral with regard to jurisdictional claims in published maps and institutional affiliations. 